\title{
Gaziantep İlinin Tarımsal Mekanizasyon Özellikleri
}

\author{
Cem BİLIM $^{1^{*}}$, Tayfun KORUCU ${ }^{2}$, Tuba SEMERCi ${ }^{1}$ \\ ${ }^{1}$ Antepfıstığı Araştırma İstasyonu Müdürlüğü, Gaziantep \\ ${ }^{2}$ KSÜ, Ziraat Fakültesi Biyosistem Mühendisliği Bölümü, Kahramanmaraş
}

Geliş (Received): 02.12.2013

Kabul (Accepted): 17.09.2014

\begin{abstract}
Özet: Tarımsal üretimin başlıca hedeflerini, birim alandan yüksek verimin elde edilerek karlılığın arttırılması, iş ve yaşam koşullarının iyileştirilmesi şeklinde sıralayabiliriz. Bu çalışmada, Gaziantep ili ve ilçelerinin mekanizasyon özellikleri; 2011 yılına ait traktör sayısı, traktör güç dağılımı ve işlenen alan değerlerinden yararlanılarak belirlenmiş ve karşılaştırmalar yapılmıştır. Karşılaştırmalarda; ortalama traktör gücü $(\mathrm{kW})$, birim alana düşen traktör gücü (kw $\mathrm{ha}^{-1}$ ), 1000 ha işlenen alana düşen traktör sayısı (traktör $1000 \mathrm{ha}^{-1}$ ) ve bir traktöre düsşen işlenen alan (ha traktör ${ }^{-1}$ ) kriterleri esas alınmıştır. Elde edilen sonuçlara göre; Gaziantep ilinde işlenen birim alana düşen traktör gücü 1.17 $\mathrm{kW} \mathrm{ha}{ }^{-1}, 1000$ ha alana düşen traktör sayıs 32.86 traktör $1000 \mathrm{ha}^{-1}$, bir traktöre düşen işlenen alan 30.44 ha traktör ${ }^{-1}$ ve ortalama traktör gücü $35.5 \mathrm{~kW}$ olarak belirlenmiștir.
\end{abstract}

Anahtar Sözcükler: Mekanizasyon, Mekanizasyon Düzeyi, Gaziantep

\section{Agricultural Mechanization Properties of Gaziantep Province}

Abstract: The main target of agricultural production is to increase productivity and improve working and living conditions. In this study, mechanization level of Gaziantep province and its districts was determined and comparisons were made by using 2010 statistical data. In the comparisons criterions as average tractor power, tractor power per unit cultivated area $\left(\mathrm{kw} \mathrm{ha}^{-1}\right)$, tractor number per 1000 ha cultivated area (tractor $\left.1000 \mathrm{ha}^{-1}\right)$ and cultivated area per tractor (ha traktör ${ }^{-1}$ ) have been taken into consideration. According to the results, tractor power per cultivated area, number of tractors per 1000 ha cultivated area, cultivated area per tractor and average tractor power in Gaziantep Province were found as $1.17 \mathrm{kw} \mathrm{ha}^{-1}, 32.86$ tractor $1000 \mathrm{ha}^{-1}, 30.44$ ha tracktor ${ }^{-1}$ and $35.5 \mathrm{~kW}$, respectively.

Key words: Agricultural mechanization, mechanization level, Gaziantep

\section{GíRiş}

Tarım sektörü gelişmekte olan tüm ülkelerde olduğu gibi, ülkemizde de ulusal ekonominin temelini oluşturmaktadır. Ülkemizde giderek artan nüfusun, besin maddelerine olan ihtiyacının tarımsal alanda üretilen ürün miktarının artırılması ile sağlanacağı artık kabul edilen bir gerçektir. Dolayısıyla, hızla çoğalan insan topluluklarının gereksinimlerini karşılamak için, birim alandan daha bol ve kaliteli üretim yapmak, günümüz tarımsal üretimin temel amaçlarındandır. $\mathrm{Bu}$ amaç, yeni teknolojilerden yararlanılarak gerçekleştirilebilir.

Endüstrisi yeteri kadar gelişmemiş ülkelerde kırsal nüfusun büyük bir kısmının açıkta bırakılması, işçi sorununa neden olacağı söylense de tarımsal mekanizasyon geliştikçe tarımla ilgili birçok iş alanları açılmaktadır ve makinenin tarıma girmesi sonucunda daha fazla bir kuvveti uğraştıracak kadar fazla olduğu ifade edilmektedir (Ülger ve ark., 2011).

Günümüzde modern tarım teknikleri deyince, toprak ve su kaynaklarının geliştirilmesi ve korunması, sulama, gübreleme, tarımsal savaş, kaliteli tohumluk kullanma ve tarımsal mekanizasyon gibi modern üretim teknolojileri akla gelmektedir. $\mathrm{Bu}$ teknolojilerden tarımsal mekanizasyon uygulamaları, tarımsal üretimde diğer tarım teknolojilerinin uygulanması ve etkinliklerinin arttırılması yönünden de oldukça büyük bir öneme sahiptir (Anonim, 2001).

Tarımsal mekanizasyon, tarımın makineleşmesidir. Tarımsal mekanizasyonun diğer teknolojilerden farklı olarak tarıma birçok yönüyle katkısı olmaktadır. Toprak işleme, tohum ekme, hasat vb. gibi işler makine ile daha iyi yapılır, dolayısıyla emeğe karşılık daha fazla kazanç elde edilir. Makine, işleri çabuk bitirerek tarımın elverişsiz hava koşullarının etkisinden kurtarır (Ülger ve ark., 1996). Mekanizasyon ileri teknolojilerin uygulanmasını, ayrıca toprak, su, gübre, ilaç vb. girdilerin etkin kullanımını olanaklı kılarak, tarımda verimliliği sağlayan önemli bir üretim aracıdır. Bunun yanı sira;

- Tarımda insan işgücü kullanımının azaltılması,

- Tarımsal verimliliğinin arttırılması,

- Temel tarımsal işlemler için zaman kaybının azaltılması ve kalitenin arttırılması en önemlileri arasında yer almaktadır.

Temel tarımsal işlerde amaca ulaşabilmek için yararlanılan mekanizasyon araçları üretim tekniği ve ürün çeşidine bağlı olarak tarımsal üretim giderlerinin \% 30-60'ını oluşturmaktadır (Dilay ve Özkan, 2007). Tarımsal mekanizasyon dışındaki diğer üretim teknolojilerinin verime doğrudan etkisi görülürken, tarımsal mekanizasyon ise planlı bir şekilde uygulandığı

\footnotetext{
*Sorumlu yazar: Bilim, C., cembilim@ hotmail.com
} 
zaman yarar sağlamaktadır. Aksi halde mekanizasyon uygulamaları yarar yerine bir yığın sorunu da beraberinde getirebilir (Ülger ve ark., 1996; Anonim, 2001).

Bir bölgede tarımsal verimliliğin arttırılması, o bölgenin tarımsal yapısına uygun mekanizasyon planlanması ile mümkün olabilmektedir. Uygun olmayan makine seçimi ve mekanizasyon planlaması işletmenin giderlerini artıracak, karlılığı azaltacaktır. Bu nedenle, işletmenin en fazla gideri oluşturan traktörekipman seçiminin doğru ve planlı yapılması tarımsal karlılık için oldukça önemlidir. $\mathrm{Bu}$ amaçla, tarımsal işlerin zamanında ve doğa koşullarına bağımlılığını kısmen azaltarak, uygun bir şekilde yapılmasını sağlayacak, asgari mekanizasyon sistemi seçilmelidir. O bölgede bulunan tarımsal işletme sayısı, hane halkı ortaklığı, işletmelerde çalışan kişilerin eğitimi, kişi sayısı, yaşları ve cinsiyetleri; hayvansal ve bitkisel üretim bakımından tarımsal işletmelerin üretim cinsleri ve üretime ayırdıkları arazi miktarları; bitkisel üretim yapan işletmelerde sulanan, sulanmayan, ekilen ekilmeyen tarıma elverişli olan arazi miktarları, üretim desenleri ve işletmelerdeki tarımsal mekanizasyon düzeyinin belirlenmesi gerekmektedir.

Tarımsal faaliyette bulunan işletmeler, genellikle işletme koşullarını ve üretim desenlerini göz önünde bulundurarak, ekonomik güçleri çerçevesinde mekanize olmaktadırlar. Bitkisel üretimdeki başlıca tarımsal faaliyetler ve kullanılan ekipmanlar, tohum yatağ hazırlama, ekim-dikim, gübreleme, ilaçlama, sulama, bakım, hasat-harman, taşıma ve ulaştırma makineleri olarak sıralanabilir. $\mathrm{Bu}$ makinelerin seçiminde işletmedeki üretim deseni ve işletme büyüklüğü göz önünde bulundurulmalıdır. Hayvancılık üretimindeki başlıca tarımsal faaliyetler, yem hazırlama makineleri, yemleme, sulama, sağım, sütün toplanması ve taşınması, ahır temizliği, gübre depolama sistemleridir.

Tarımsal makineleşmede söz konusu gösterge değerlerinin incelenmesinde, sadece sayısal verilerin yüksekliği yeterli olmamaktadır. Bir ülkenin veya bölgenin tarımının makineleşmesinin bir göstergesi olan tarımsal mekanizasyon düzeyinin belirlenmesinde birçok farklı ölçüt kullanılmaktadır. Göstergelerin birbiriyle uyumu, makine ve traktörün yıllık çalışma süresi, traktör kullanılan işletme sayısı, işletmeye düşen traktör sayısı gibi faktörlerde göz öz önünde tutulmalıdır. Tarımda mekanizasyon işlemleri, çok büyük oranda traktörle çalıştırılan iş makineleri ile gerçekleştirilmektedir. $\mathrm{Bu}$ nedenle, traktör bir ülkenin mekanizasyon düzeyinin belirlenmesinde en önemli göstergedir.

Türkiye'nin bölgeler itibariyle mekanizasyon düzeyi Çizelge 1'de verilmiştir. Bu çizelgede ayrıca Türkiye'de ortalama traktör gücünün $41.05 \mathrm{~kW}$, işlenen birim alana düşen traktör gücünün $2.91 \mathrm{~kW} \mathrm{ha}{ }^{-1}, 1000$ ha tarım alanına düşen traktör sayısının 71 traktör $1000 \mathrm{ha}^{-1}$, bir traktöre düşen tarım alanının 14.8 ha traktör ${ }^{-1}$, bir traktöre düşen alet ekipman sayısının 6.32 makine traktör $^{-1}, 1000$ ha alana düşen biçerdöver sayısının 0.90 biçerdöver $1000 \mathrm{ha}^{-1}$ olduğu görülmektedir (Sessiz ve ark., 2012).

Çizelge 1. Türkiye ve bölgeler itibariyle mekanizasyon düzeyi (Yalçın, 1990)

\begin{tabular}{|c|c|c|c|c|c|c|}
\hline Bölgeler & $\begin{array}{l}\text { Ortala } \\
\text { ma } \\
\text { Traktör } \\
\text { Gücü } \\
(\mathrm{kW})\end{array}$ & $\begin{array}{c}\text { Birim } \\
\text { Alana } \\
\text { Düşen } \\
\text { Traktör } \\
\text { Gücü } \\
\left(\mathrm{kW} \mathrm{ha}{ }^{-1}\right) \\
\end{array}$ & $\begin{array}{c}1000 \text { ha Alana } \\
\text { Düşen Traktör } \\
\text { Sayis1 } \\
\text { (traktör } 1000 \\
\text { ha }^{-1} \text { ) }\end{array}$ & $\begin{array}{c}\text { Bir Traktöre } \\
\text { Düşen Tarım } \\
\text { Alanı } \\
\text { (ha traktör }{ }^{-1} \text { ) }\end{array}$ & $\begin{array}{l}\text { Bir Traktöre } \\
\text { Düşen Alet } \\
\text { Ekipman } \\
\text { Sayısı } \\
(\text { makine } \\
\left.\text { traktör }^{-1}\right) \\
\end{array}$ & $\begin{array}{l}\text { 1000ha'lık } \\
\text { Alana Düşen } \\
\text { Biçerdöver } \\
\text { Sayısı } \\
\text { (biçerdöver } \\
1000 \text { ha }^{-1} \text { ) }\end{array}$ \\
\hline $\begin{array}{l}\text { Kuzeydoğu } \\
\text { Anadolu }\end{array}$ & 54.60 & 1.36 & 24.82 & 40.29 & 6.04 & 0.32 \\
\hline İstanbul & 59.50 & 4.92 & 82.71 & 12.09 & 6.84 & 1.74 \\
\hline Batı Marmara & 54.83 & 5.03 & 91.74 & 10.90 & 7.00 & 2.18 \\
\hline Ege & 48.20 & 6.55 & 135.87 & 7.36 & 6.26 & 0.52 \\
\hline Doğu Marmara & 47.37 & 6.94 & 146.46 & 6.83 & 6.37 & 1.59 \\
\hline Batı Anadolu & 55.96 & 2.35 & 41.91 & 23.86 & 7.86 & 0.98 \\
\hline Akdeniz & 50.91 & 4.03 & 79.10 & 12.64 & 7.04 & 1.10 \\
\hline Orta Anadolu & 53.19 & 2.73 & 51.27 & 19.50 & 5.37 & 1.18 \\
\hline Batı Karadeniz & 47.60 & 5.24 & 110.17 & 9.08 & 4.90 & 0.96 \\
\hline Doğu Karadeniz & 35.13 & 2.50 & 71.29 & 14.03 & 10.13 & 0.01 \\
\hline Türkiye & 41.05 & 2.91 & 71.00 & 14.08 & 6.32 & 0.90 \\
\hline Avrupa Birliği & 100 & 6 & 89 & 11.3 & 10 & - \\
\hline
\end{tabular}

İleri tarım tekniklerinin uygulanabilmesi ve istenilen sonuçlara ulaşılması mekanizasyonda kullanılan makinelerin yapısına ve bilinçli kullanımına bağlıdır (Yalçın, 1990). Tarımsal üretimde kullanılan temel güç kaynağı traktördür. $\mathrm{Bu}$ nedenle, mekanizasyon düzeyinin belirlenmesinde dikkate alınan birim işlenen alana düşen traktör gücü, bugüne kadar en yaygın kullanılan kriter olmuştur. $\mathrm{Bu}$ değerlerin sağlıklı bir şekilde belirlenmesi, mekanizasyon düzeyi boyutunun 
da daha gerçekçi saptanmasına olanak sağlayacaktır (Sabancı ve Akınc1, 1994).

Bir ilin tarımının gelişmesi, tarım makineleri imalat sanayisinin gelişmesine ve tarımda makine kullanımına bağlıdır. Gaziantep önemli bir tarımsal alan ve üretim potansiyeline sahip olmasına rağmen, il düzeyinde mekanizasyon düzeyinin ve tarım makineleri imalat sanayisinin durumunun ne olduğu bilinmemektedir. $\mathrm{Bu}$ çalışmanın amacı, tarımsal mekanizasyonun çă̆daş aracı olan traktör ve tarım alet makine varlığı ile işlenen alan parametrelerini esas alarak, Gaziantep ili ve ilçelerinin mekanizasyon düzeyini belirlemektir.

\section{MATERYAL ve YÖNTEM}

Çalışma materyalini Gaziantep ili ve ilçelerine ait Türkiye İstatistik Kurumu'nun (TUİK) 2011 y1lı verileri oluşturmuştur. Veriler arasında Gaziantep ili ve ilçelerine ait işlenen alan ve traktör varlığının yanı sıra; önemli bazı toprak işleme alet ve makineleri, ekimdikim ve gübreleme makineleri, tarımsal savaş makineleri, hasat ve harman makineleri ile diğer bazı önemli tarımsal alet ve makinelerin varlığına yer verilmiştir. Araştırmada, toplam işlenen alan değerlerinin belirlenmesinde; meyve, içecek ve baharat bitkileri üretim alanları, traktör sayısı ve ortalama güç büyüklüğü değerlerinin belirlenmesinde ise tek akslı traktörler dikkate alınmamıştır.

Gaziantep ili ve ilçelerinin mekanizasyon düzeyinin belirlenmesinde aşağıda verilen ölçütler kullanılmıştır.
1. Birim alana düşen traktör gücü $\left(\mathrm{kw} \mathrm{ha}{ }^{-1}\right)$ : Mevcut mekanik gücün toplam işlenen alana bölünmesiyle hesaplanmıştır.

2. Traktör başına düşen tarım alanı (ha traktör ${ }^{-1}$ ) : Toplam tarım alanının güç değerlerine bakılmaksızın traktör sayısına bölünmesiyle belirlenmiştir.

3. Birim alan başına düşen traktör sayısı (traktör $1000 \mathrm{ha}^{-1}$ ) : Toplam traktör sayısının işlenen tarım alanına bölünmesiyle elde edilmiştir.

4. Traktör başına düşen alet-ekipman sayısı (makine traktör ${ }^{-1}$ ) : toplam alet-ekipman sayısının toplam traktör sayısına bölünmesiyle hesaplanmıştır (Erkmen ve Çelik, 1992; Çelik ve ark., 2002; Altıkat ve Çelik, 2009).

\section{BULGULAR ve SONUÇLAR}

Tarımsal Mekanizasyon Düzeyi

Tarımsal mekanizasyon düzeyinin belirlenmesinde, bir ile ait toplam işlenen alan, traktör sayısı, ortalama traktör gücü, ve ekipman sayısı değerlerinden yararlanılmıştır. Belirtilen bu değerler Gaziantep ili için TUIK (2011) verilerinden alınmıştır (Çizelge 2). Toplam traktör sayısı bütün güç gruplarındaki traktörlerin toplanması ile bulunmuştur. Toplam traktör gücü ise her gücün ortalaması alınarak o güçteki traktör sayısı ile çarpılarak hesaplanmıştır. Toplam ekipman sayısı ise traktör ile çalıştırılabilen bütün ekipmanların toplanması ile elde edilmiştir.

Çizelge 2. Gaziantep ili tarım alanı ve tarım makineleri varlığı (Anonim, 2011a; Anonim, 2011b)

\begin{tabular}{lrrrr} 
& $\begin{array}{c}\text { Toplam traktör } \\
(\text { adet })\end{array}$ & $\begin{array}{c}\text { Toplam traktör gücü } \\
(\mathrm{kW})\end{array}$ & $\begin{array}{c}\text { Toplam alan } \\
(\text { ha })\end{array}$ & $\begin{array}{c}\text { Toplam ekipman } \\
\text { (adet) }\end{array}$ \\
\hline Şahinbey & $\mathbf{2 3 4 7}$ & $\mathbf{7 7 2 3 8}$ & $\mathbf{5 2 ~ 9 1 8}$ & $\mathbf{7 8 4 3}$ \\
Şehitkamil & 1060 & 34614 & 31799 & 3592 \\
Araban & 997 & 41016 & 32110 & 5319 \\
İslahiye & 721 & 27876 & 28899 & 2933 \\
Kargamiş & 875 & 28579 & 27204 & 3072 \\
Nizip & 1652 & 58366 & $\mathbf{6 5 ~ 8 2 2}$ & $\mathbf{6 8 4 6}$ \\
Nurdağ1 & 833 & 35381 & 18595 & 3833 \\
Oğuzeli & 1344 & 46041 & $\mathbf{3 9 ~ 8 0 5}$ & $\mathbf{6 2 9 1}$ \\
Yavuzeli & $\mathbf{3 4 4}$ & $\mathbf{1 2 2 0 4}$ & 12474 & 1079 \\
\hline Toplam & 10173 & 361316 & 309627 & 40808 \\
\hline
\end{tabular}

Gaziantep ilçelerinin sahip oldukları traktör sayısı ve toplam traktör gücü değerleri bakımından ilçeler arasında önemli farklılıkların olduğu görülmektedir. Gerek traktör sayısı bakımından ve gerekse traktör gücü değerleri bakımından Şahinbey ilçesi ilk sırayı almaktadır. Bunu sırasıyla Nizip ve Oğuzeli ilçeleri izlemiştir. İşlenebilir tarımsal alan bakımından da ilçeler arasında önemli farklılıkların olduğu görülmektedir. Nizip, Şahinbey ve Oğuzeli ilçeleri diğer ilçelere göre çok daha fazla tarımsal alana sahiptir. Benzer şekilde toplam ekipman bakımından da aynı ilçelerin ön sıralarda yer aldığı görülmektedir.

Gaziantep ili genelinde toplam 10.173 traktör bulunmaktadır. $\mathrm{Bu}$ traktörlerin tamamı iki akslı traktörlerden oluşmaktadır (Çizelge 3). İki akslı traktörler içerisinde 7.017 adet ile $35-50 \mathrm{~kW}$ güç grubunda bulunan traktörler ilk sırada bulunmaktadırlar. En az güç sınıfinda ise 11-24 kW'lık güç sınıfinın olduğu görülmektedir (Anonim, 2011a). 
Çizelge 3. Gaziantep ili genelinde bulunan traktörlerin güç sınıflarına göre dağılımı (Anonim, 2011a)

\begin{tabular}{|c|c|c|c|c|c|c|c|c|}
\hline \multirow{2}{*}{ İlçeler } & \multirow{2}{*}{$\begin{array}{l}\text { Tek Akslı Traktör } \\
\text { Güç sınıfı } \\
(1-5 \mathrm{~kW})\end{array}$} & \multicolumn{5}{|c|}{ İki Akslı Traktör Güç sınıfı(kW) } & \multicolumn{2}{|c|}{ Toplam } \\
\hline & & $11-24$ & $25-34$ & $35-50$ & $51-70$ & $70+$ & Adet & $\%$ \\
\hline Şahinbey & 12 & 0 & 0 & 2020 & 315 & 0 & 2347 & 23.07 \\
\hline Şehitkamil & 0 & 0 & 0 & 950 & 110 & 0 & 1060 & 10.42 \\
\hline Araban & 3 & 0 & 2 & 385 & 475 & 132 & 997 & 9.80 \\
\hline İslahiye & 6 & 0 & 8 & 335 & 327 & 45 & 721 & 7.09 \\
\hline Kargamış & 0 & 0 & 0 & 800 & 60 & 15 & 875 & 8.60 \\
\hline Nizip & 0 & 0 & 27 & 1160 & 410 & 55 & 1652 & 16.24 \\
\hline Nurdağ 1 & 10 & 3 & 0 & 90 & 730 & 0 & 833 & 8.19 \\
\hline Oğuzeli & 0 & 0 & 0 & 1042 & 302 & 0 & 1344 & 13.21 \\
\hline Yavuzeli & 0 & 0 & 0 & 235 & 109 & 0 & 344 & 3.38 \\
\hline Toplam & 31 & 3 & 37 & 7017 & 2838 & 247 & 10173 & 100 \\
\hline$\%$ & 0.3 & 0.03 & 0.36 & 68.98 & 27.90 & 2.43 & & \\
\hline
\end{tabular}

Traktör varlığının ilçelere oransal dağılımı incelendiğinde \% 23.07 ile Şahinbey ilçesi birinci sırayı alırken, bunu \% 16.24 ile Nizip ilçesi, \% 13.21 ile de Oğuzeli ilçeleri alırken, bunu sırasıyla Şehitkamil, Araban ve Nurdağı ilçelerinin takip ettiği görülmektedir.

İl genelinde kullanılan iki akslı traktörlerin güç sınıflarına göre oransal dağılımı incelendiğinde 35-50 $\mathrm{kW}$ gücündeki traktörlerin $\% 68.98$ ile ilk sırayı aldıkları, bunu sirasıyla \% 27.90 ile $51-70 \mathrm{~kW}$ ve $\%$
2.43 ile $70+\mathrm{kW}$ 'lik güce sahip traktörlerin aldığ 1 görülmektedir. En az güç sınıfını \% 0.03 ile 11-24 kW izlediği görülmektedir.

Çizelge 2'de verilen değerler kullanılarak Gaziantep ili için mekanizasyon düzeyi kriterleri hesaplanmıştır (Çizelge 4). Çizelgede ayrıca bu kriterlerin Türkiye ortalamaları da verilmiștir (sessiz ve ark., 2012). Gaziantep ilçeleri mekanizasyon kriterlerine ait yersel değişimler ise ArcMap 10 programı kullanılarak haritalanmıştır (Şekil 1-5).

Çizelge 4. Gaziantep ili mekanizasyon düzeyleri

\begin{tabular}{|c|c|c|c|c|c|c|}
\hline İlçe & $\begin{array}{l}\text { Ortalama } \\
\text { Traktör } \\
\text { Gücü } \\
(\mathrm{kW} \\
\left.\text { traktör }^{-1}\right)\end{array}$ & $\begin{array}{c}\text { Birim Alana } \\
\text { Düşen Traktör } \\
\text { Gücü } \\
\left(\mathrm{kW} \mathrm{ha}^{-1}\right)\end{array}$ & $\begin{array}{c}1000 \text { ha Alana } \\
\text { Düşen Traktör } \\
\text { Sayis1 } \\
\text { (traktör } 1000_{\text {ha }^{-1} \text { ) }}\end{array}$ & $\begin{array}{c}\text { Bir Traktöre } \\
\text { Düşen Tarım } \\
\text { Alanı } \\
\text { (ha traktör }{ }^{-1} \text { ) }\end{array}$ & $\begin{array}{c}\text { Bir Traktöre } \\
\text { Düşen Alet } \\
\text { Ekipman } \\
\text { Sayısı } \\
\text { (makine } \\
\text { traktör }^{-1} \text { ) }\end{array}$ & $\begin{array}{c}\text { Biçerdöver Sayısı } \\
\text { (biçerdöver } 1000 \\
\text { ha }^{-1} \text { ) }\end{array}$ \\
\hline Şahinbey & 32.9 & 1.46 & 44.35 & 22.55 & 3.34 & 0.23 \\
\hline Şehitkamil & 32.7 & 1.09 & 33.33 & 30.00 & 3.39 & 0.09 \\
\hline Araban & 41.1 & 1.28 & 31.05 & 32.21 & 5.34 & \\
\hline Islahiye & 38.7 & 0.96 & 24.95 & 40.08 & 4.07 & \\
\hline Kargamış & 32.7 & 1.05 & 32.16 & 31.09 & 3.51 & \\
\hline Nizip & 35.3 & 0.89 & 25.10 & 39.84 & 4.14 & \\
\hline Nurdağ 1 & 42.5 & 1.90 & 44.80 & 22.32 & 4.60 & 0.05 \\
\hline Oğuzeli & 34.3 & 1.16 & 33.76 & 29.62 & 4.68 & 0.13 \\
\hline Yavuzeli & 35.5 & 0.98 & 27.58 & 36.26 & 3.14 & \\
\hline Gaziantep & 35.5 & 1.17 & 32.86 & 30.44 & 4.01 & 0.50 \\
\hline Türkiye* & 41.05 & 2.91 & 71 & 14.8 & 6.32 & 0.90 \\
\hline $\begin{array}{l}\text { Avrupa } \\
\text { Birliği** }\end{array}$ & 100 & 6 & 89 & 11.3 & 10 & - \\
\hline
\end{tabular}

Gaziantep ili ortalama traktör gücü $35.5 \mathrm{~kW}$ 'dır. Bu değer Türkiye ortalamasından \%14, Avrupa Birliği ortalamasından ise \% 65 daha düşüktür. Ortalama traktör gücü değeri ilçeler bazında incelendiğinde hem Nurdağı hem de Araban ilçelerinin Türkiye ortalamasının üzerinde veya eş değer olduğu görülmektedir. Oğuzeli, Kargamış, Şehitkamil ve Şahinbey ilçeleri ise ortalama traktör gücü bakımından il ortalamasının altında kalmaktadır.
Tarımsal mekanizasyon uygulamalarında en yaygın kullanılan kuvvet kaynağı traktördür. $\mathrm{Bu}$ nedenle bir bölgenin mekanizasyon düzeyi belirlenirken dikkate alınan en önemli ölçü birimi işlenen alana düşen traktör gücü $\left(\mathrm{kW} \mathrm{ha}{ }^{-1}\right)$ olmaktadır. $\mathrm{Bu}$ ölçüt makineleşme düzeyinin belirlenmesinde en doğru ölçüt olarak kabul edilmektedir. Birim alana düşen traktör gücü, Avrupa Birliği ülkeleri için ortalama $6 \mathrm{~kW} \mathrm{ha}^{-1}$ iken bu değerin Türkiye ortalaması $2.91 \mathrm{~kW} \mathrm{ha}^{-1}$, Gaziantep ili 
ortalaması ise $1.17 \mathrm{~kW} \mathrm{ha}{ }^{-1}$ dır. Türkiye ortalaması Avrupa Birliği ülkelerinin ortalamasına göre \% 52 daha düşük, Gaziantep ile ise Türkiye ortalamasına göre $\%$ 60 daha düşük değerdedir. Bu değer Gaziantep ilindeki mekanizasyon seviyesinin oldukça geride olduğunun açık bir göstergesidir. İlçeler bazında inceleme yapıldığında Nurdağı ilçesi $1.90 \mathrm{~kW} \mathrm{ha}{ }^{-1}$ ile ilk sırayı alırken Nizip ilçesi $0.89 \mathrm{~kW} \mathrm{ha}^{-1}$ ile en son sırada yer almaktadır. Nurdağı ilçesi sahip olduğu traktör sayısı ve traktörlerin sahip oldukları güç bakımından diğer ilçelere göre düşük olmasına rağmen, toplam tarım alanlarının da düşük olması birim alana düşen ortalama güç miktarının yükselmesine neden olmuştur. Nizip ilçesi traktör sayısı ve toplam traktör gücü en yüksek ikinci ilçe olmasına rağmen, toplam tarım alanı en geniş olan ilçe olması nedeni ile birim alana düşen ortalama güç miktarı en düşük ilçe olmasına neden olmuştur.

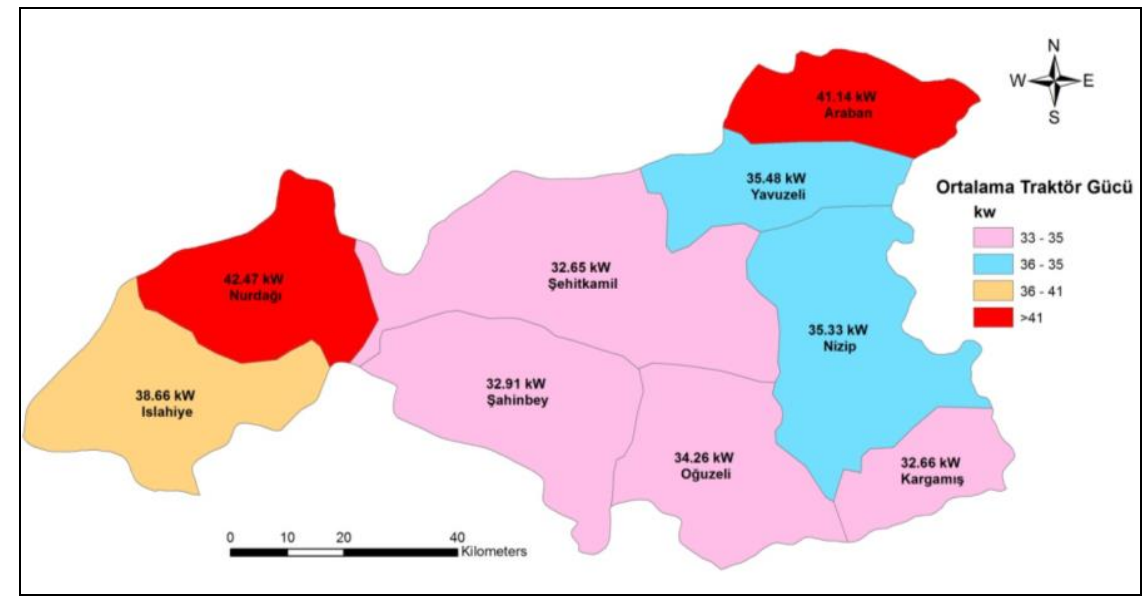

Şekil 1. Gaziantep ili ortalama traktör gücü değerlerinin ilçelere göre dağılımı

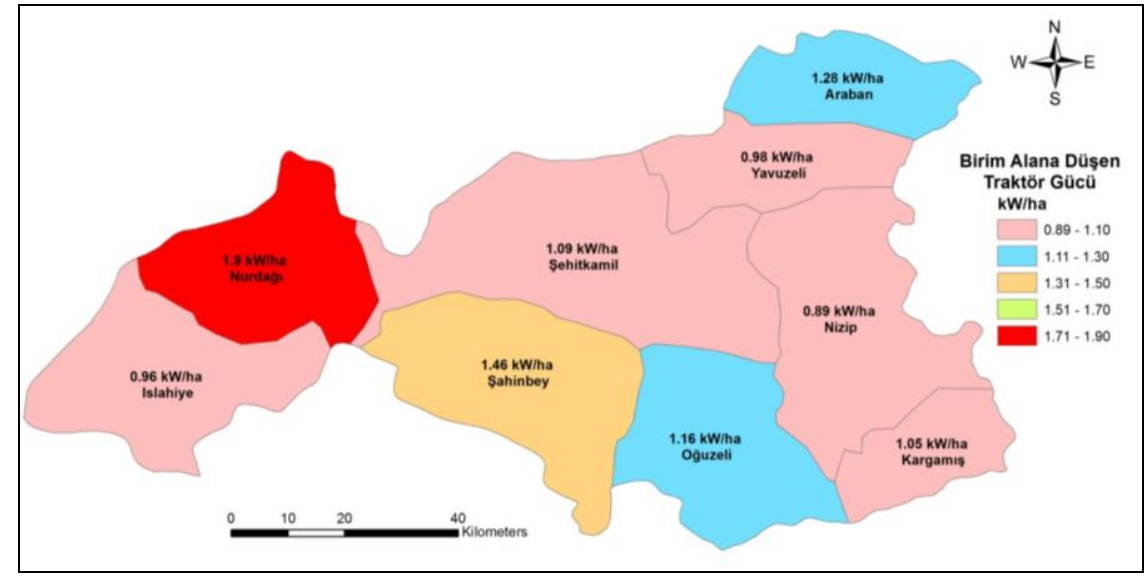

Şekil 2. Gaziantep ili birim alana düşen traktör gücü değerlerinin ilçelere göre dağılımı 


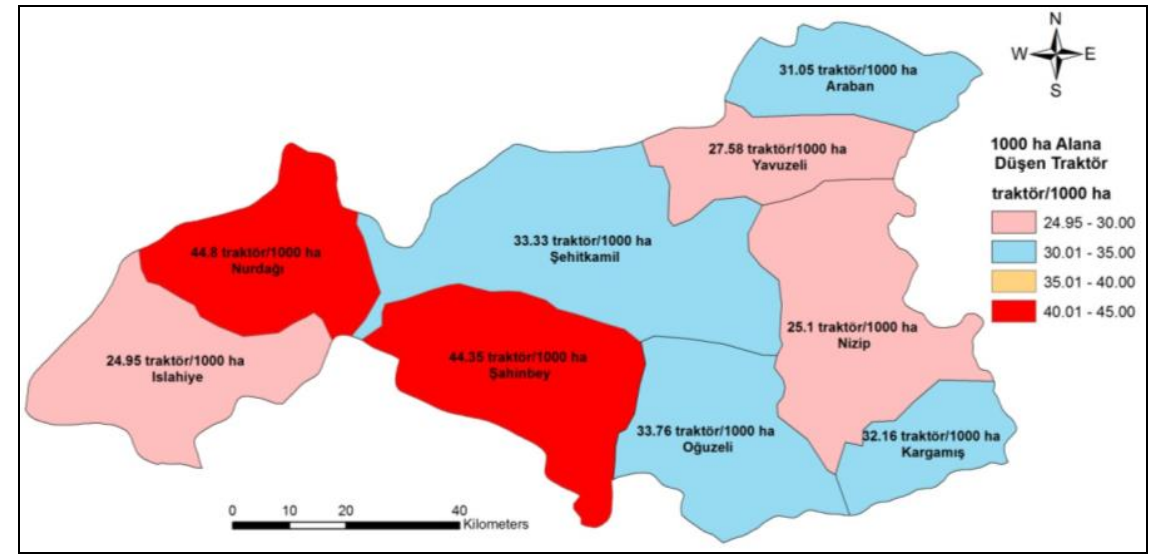

Şekil 3. Gaziantep ili 1000 ha alana düşen traktör değerlerinin ilçelere göre dağılımı

Mekanizasyon düzeyinin önemli göstergelerinden biriside 1000 ha işlenen alana düşen traktör sayısı (traktör 1000 ha $^{-1}$ )'dır. 1000 ha işlenen alana düşen traktör sayısı (traktör $1000 \mathrm{ha}^{-1}$ ) bakımından Nurdağı ilçesi 44.8 traktör ile ilk sırada yer alırken, traktör başına düşen alan bakımından (22.32 ha traktör $\left.{ }^{-1}\right)$ son sırada yer almaktadır. Bu durum Nurdağı ilçesinin toplam alanının düşük olmasından kaynaklanmaktadır. İslahiye ilçesi ise 24.95 traktör $1000 \mathrm{ha}^{-1}$ ile en son sırada, 40.08 ha traktör ${ }^{-1}$ ile ilk sırada bulunmaktadır.
Tüm ilçelerin ortalaması dikkate alındığında Gaziantep ilinde 1000 ha işlenen alana düşen traktör sayısının 32.86 traktör $1000 \mathrm{ha}^{-1}$ olduğu görülmektedir. $\mathrm{Bu}$ değerin Türkiye ortalaması 71 traktör $1000 \mathrm{ha}^{-1}$, Avrupa Birliği ortalaması ise 89 traktör $1000 \mathrm{ha}^{-1}$ dır. 1000 ha işlenen alana düşen traktör sayısı bakımından Türkiye Avrupa Birliği ülkelerinin \% 20 gerisinde yer alırken, Gaziantep ili'de Türkiye ortalamasının \% 54 gerisinde yer almaktadır.

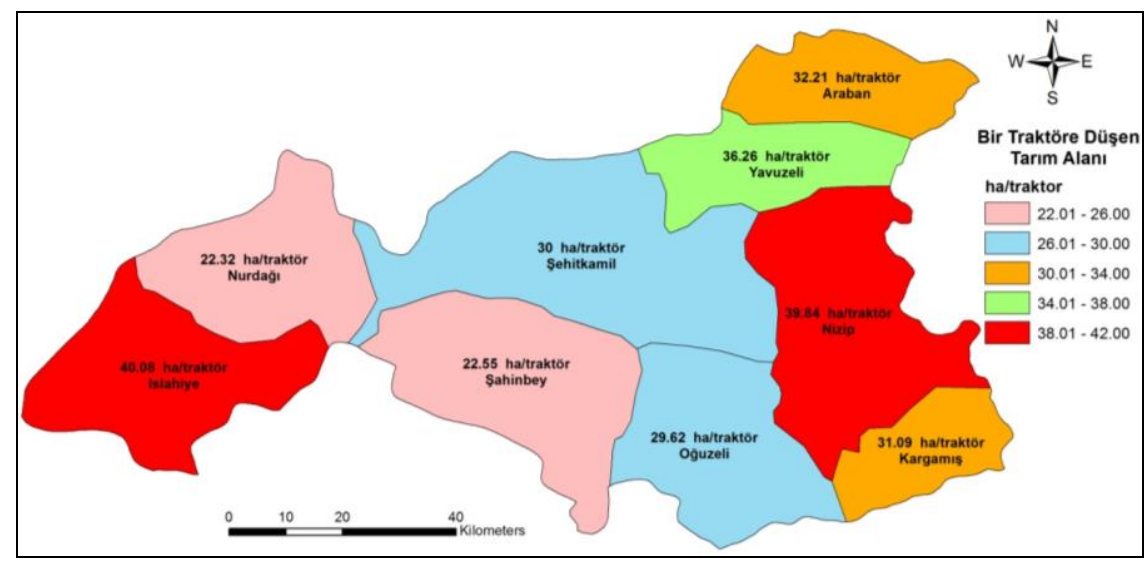

Şekil 4. Gaziantep ili bir traktöre düşen tarım alanı değerlerinin ilçelere göre dağılımı

Tüm ilçelerin ortalaması dikkate alındığında Gaziantep ile traktör başına düşen tarım alanı ortalaması 30.44 ha traktör ${ }^{-1}$ 'dır. Bu değerin Türkiye ortalaması 14.8 ha traktör ${ }^{-1}$, Avrupa Birliği ortalaması ise 11.3 ha traktör $^{-1}$ dır. Bu değerin düşük olması mekanizasyon seviyesinin yüksek olmasını ifade etmektedir. Buna göre traktör başına düşen tarım alanı bakımından Türkiye Avrupa Birliği ülkelerinin \% 31 gerisinde yer alırken, Gaziantep ili'de Türkiye ortalamasının \% 105 gerisinde yer almaktadır. 


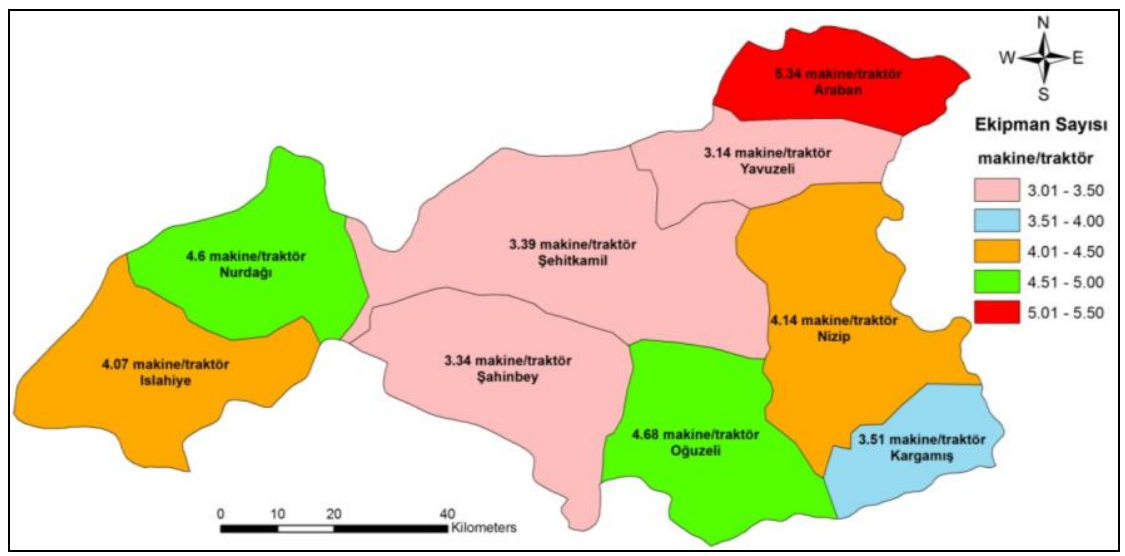

Şekil 5. Gaziantep ili traktör başına düşen alet-makine sayısının ilçelere göre dağılımı

Tarımsal mekanizasyonun düzeyinin traktörden sonraki en önemli göstergesi traktör başına düşen aletmakine varlığıdır. Çizelge 4 ve Şekil 5 incelendiğinde; traktör başına düşen alet-makine sayısı bakımından Araban ilçesi 5.3 makine traktör ${ }^{-1}$ değeri ile ilk sırayı alırken, bu ilçeyi 4.68 makine traktör ${ }^{-1}$ değeri ile Oğuzeli ilçesi izlemiştir. Yavuzeli ilçesi ise 3.14 makine traktör ${ }^{-1}$ değeri ile son sırada yer almıştır. Tüm ilçelerin ortalaması alındığında Gaziantep ili 4.01 makine traktör ${ }^{1}$ değerine sahiptir. Traktör başına düşen alet-makine sayısı bakımından Türkiye 6.3 makine traktör ${ }^{-1}$, Avrupa Birliği ise 10 makine traktör ${ }^{-1}$ ortalamalarına sahiptirler. Türkiye Avrupa Birliği ülkelerinin \% 39 gerisinde yer alırken, Gaziantep ili'de Türkiye ortalamasının \% 37 gerisinde yer almaktadır. Dünya ve ülke ortalamaları veya aynı il içinde farklı ilçelerin karşılaştırmaları yapılırken yanlış yorum yapma olasılığg çok yüksektir. Bir ilçede bahçe tarımı veya bağcılık yaygınken bir diğerinde tarla tarımı yaygın olabilir. Bahçe tarımı yapılan ve ortalama arazi miktarı işletme başına düşük olan bir işletme için küçük güçlü bir traktör kullanılması mekanizasyon düzeyinin düşük olduğunu göstermeyebilir.

\section{Tarım Alet ve Makine Varlığı}

Gaziantep ili ve ilçelerinde bulunan önemli bazı toprak işleme alet ve makine sayıları Çizelge 5'te verilmiştir.

Çizelge 5. İlçeler bazında önemli bazı toprak işleme alet ve makinelerinin varlı̆̆ (Anonim, 2011a)

\begin{tabular}{lcccccccc} 
İlçeler & $\begin{array}{c}\text { Kulaklı } \\
\text { Pulluk } \\
\text { (adet) }\end{array}$ & $\begin{array}{c}\text { Diskli } \\
\text { Pulluk } \\
\text { (adet) }\end{array}$ & $\begin{array}{c}\text { Diskli } \\
\text { Tirmik } \\
\text { (adet) }\end{array}$ & $\begin{array}{c}\text { Kültivatör } \\
\text { (adet) }\end{array}$ & $\begin{array}{c}\text { Merdane } \\
\text { (adet) }\end{array}$ & $\begin{array}{c}\text { Toprak } \\
\text { Frezesi } \\
\text { (adet) }\end{array}$ & $\begin{array}{c}\text { Dişli } \\
\text { Tirmık } \\
\text { (adet) }\end{array}$ & $\begin{array}{c}\text { Toplam } \\
\text { (adet) }\end{array}$ \\
\hline Şahinbey & 1600 & 200 & 15 & 1300 & 80 & 60 & 8 & 3263 \\
Şehitkamil & 500 & 100 & 12 & 550 & 20 & 1 & 10 & 1193 \\
Araban & 746 & 1 & 4 & 945 & 8 & 8 & 5 & 1717 \\
İslahiye & 400 & 15 & 97 & 662 & 90 & 40 & 50 & 1354 \\
Kargamış & 604 & 32 & 12 & 750 & 35 & 15 & 0 & 1448 \\
Nizip & 950 & 260 & 16 & 1550 & 80 & 20 & 11 & 2887 \\
Nurdağ1 & 700 & 26 & 145 & 430 & 50 & 92 & 26 & 1469 \\
Oğuzeli & 810 & 110 & 115 & 1274 & 126 & 12 & 30 & 2477 \\
Yavuzeli & 201 & 14 & 0 & 260 & & 21 & 8 & 504 \\
\hline Gaziantep & $\mathbf{6 5 1 1}$ & 758 & 416 & $\mathbf{7 7 2 1}$ & 489 & 269 & $\mathbf{1 4 8}$ & 16312 \\
\hline
\end{tabular}

Çizelge 5 incelendiğinde, il genelinde en yaygın kullanılan toprak işleme aletlerinin \% 47.33 ile kültivatör ve \% 39.92 ile kulaklı pulluk olduğu görülmektedir. Bunu sırasıyla; diskli pulluk (\% 4.65), merdane (\% 3), diskli tırmık (\% 2.55), toprak frezesi (\% $1.65)$ ve dişli tırmık $(\% 0.91)$ takip etmektedir. Toprak frezesi her ne kadar tek geçişte tohum yatağı hazırlama avantajına sahip ise de, sayıları itibariyle il genelinde kullanımının oldukça sınırlı olduğu söylenebilir. Toprak işleme alet ve makineleri verilerinden yola çıkılarak değerlendirme yapıldığında, il genelinde geleneksel toprak işleme yönteminin yoğun bir şekilde uygulandığ 1 sonucuna varılabilir.

Toprak işleme alet ve makinelerinin ilçelere göre dağılımı incelendiğinde; ilde bulunan alet ve makinelerinin \% 20.00'1 Şahinbey ilçede, \% 17.70'i Nizip ve \% 15.19'u Oğuzeli ilçelerinde bulunurken, en az alet ve makine varlığının \% 3.09 ile Yavuzeli ilçesinde olduğu görülmektedir. Gaziantep ili genelinde bulunan önemli bazı bitki koruma makineleri Çizelge 6'da verilmiştir. Bitki koruma makineleri verilerinden tarımsal mücadelede çoğunlukla sırt pülverizatörünün kullanıldığ 1 (\% 55.15), bunu kuyruk milinden hareketli 
pülverizatör (\% 39.33) ve motorlu pülverizatörün (\% 5.52) takip ettiği görülmektedir (Çizelge 6). Sirt pülverizatörünün ilçelerde yaygın bulunan meyve ve sebze bahçelerinin yanı sıra, tarla alanlarında da etkin bir şekilde kullanıldığı anlaşılmaktadır.

Çizelge 6. Gaziantep ili bitki koruma makinelerinin ilçelere göre dağılımı (Anonim, 2011a)

\begin{tabular}{lcccc}
\hline \multicolumn{1}{c}{ İlçeler } & Sirt Pülverizatörü & Kuyruk Milinden Hareketli Pülverizatör & Motorlu Pülverizatör & $\begin{array}{c}\text { Toplam } \\
\text { (adet) }\end{array}$ \\
\hline Şahinbey & 550 & 160 & 25 & 735 \\
Şehitkamil & 600 & 90 & 14 & 704 \\
Araban & 815 & 570 & 5 & 1390 \\
İlahiye & 235 & 80 & 33 & 348 \\
Kargamış & 73 & 207 & 5 & 285 \\
Nizip & 600 & 650 & 95 & 1345 \\
Nurdağ1 & 73 & 200 & 110 & 383 \\
Oğuzeli & 302 & 365 & 40 & 707 \\
Yavuzeli & 16 & 6 & 327 & 22 \\
\hline Gaziantep & 3264 & 2328 & 3919 \\
\hline
\end{tabular}

Bitki koruma makinelerinin ilçelere göre dağılımında, \% 23.48'lik oran ile Araban ilçesi başı çekerken, bunu \% 22.72 ile Nizip, \% 12.42 ile Şahinbey ve \% 11.89 ile Şehitkamil ilçeleri takip ederken \% 0.37 lik değer ile Yavuzeli ilçesi en son sırada yer almaktadır. Araban ilçesinde yaygın olarak kullanılması bu ilçede bulunan meyve ve sebze bahçelerinin daha fazla olmasından kaynaklanmaktadır. Bunun yanı sıra, Yavuzeli ilçesinde ilaçlama makinasının yok denecek kadar az olmasına neden olarak, bahçelerin agroteknik isteklere uygun kurulmayışı gösterilebilir.
Gaziantep ili ve ilçelerinde bulunan ekim-dikim ve gübreleme makineleri varlığı Çizelge 7'de verilmiştir. Gaziantep ilinde kimyevi gübre dağıtma makinesi toplam 2.325 adet olup, bu makinelerin çoğunluğu Araban ilçesinde bulunmaktadır. Yöre halkı kimyevi gübre dağıtma makinesini serpme ekim yönteminde kullanabilmektedir. İlde anıza doğrudan ekim makinesi bulunmadığı için doğrudan ekim uygulaması da söz konusu değildir.

Çizelge 7. Gaziantep ili ekim-dikim ve gübreleme makineleri varlığının ilçelere göre dağılımı (Anonim, 2011a)

\begin{tabular}{|c|c|c|c|c|c|c|}
\hline İlçeler & $\begin{array}{l}\text { Pnömatik } \\
\text { Ekim } \\
\text { Makinesi }\end{array}$ & $\begin{array}{c}\text { Traktörle Çekilen } \\
\text { Hububat Ekim } \\
\text { Makinesi }\end{array}$ & $\begin{array}{l}\text { Kombine } \\
\text { Ekim } \\
\text { Makinesi }\end{array}$ & $\begin{array}{l}\text { Çiftlik Gübresi } \\
\text { Dağıtma } \\
\text { Makinası }\end{array}$ & $\begin{array}{l}\text { Santrifüjlü Gübre } \\
\text { Dağıtma Makinası }\end{array}$ & $\begin{array}{l}\text { Toplam } \\
\text { (adet) }\end{array}$ \\
\hline Şahinbey & 60 & 250 & 500 & 20 & 250 & 1080 \\
\hline Şehitkamil & 4 & 15 & 10 & 0 & 50 & 79 \\
\hline Araban & 25 & 19 & 121 & 0 & 520 & 685 \\
\hline İslahiye & 22 & 69 & 40 & 12 & 150 & 293 \\
\hline Kargamış & 0 & 250 & 0 & 0 & 201 & 451 \\
\hline Nizip & 0 & 200 & 280 & 3 & 240 & 723 \\
\hline Nurdağ1 & 6 & 99 & 220 & 2 & 401 & 728 \\
\hline Oğuzeli & 0 & 11 & 755 & 0 & 450 & 1216 \\
\hline Yavuzeli & 0 & 47 & 9 & 0 & 63 & 119 \\
\hline Gaziantep & 117 & 960 & 1935 & 37 & 2325 & 5374 \\
\hline
\end{tabular}

Gaziantep il genelinde önemli bazı ekim-dikim ve gübreleme makineleri içerisinde santrifüjlü gübre dağıtma makinesinin (\% 43.26) ilk sirada yer aldığı dikkat çekmektedir. Bunu sırası ile; kombine ekim makinesi (\% 36.01), traktörle çekilen hububat ekim makinesi (\% 4.65), pnömatik ekim makinesi (\% 2.18) ve çiftlik gübresi dağıtma makinesi (\% 0.69) takip etmektedir.

Ekim-dikim ve gübreleme makinelerinin ilçelere göre dağılımı incelendiğinde; ilde bulunan alet ve makinelerinin \% 22.63'ü Oğuzeli ilçesinde, \% 20.10'u Şahinbey, \% 13.55'i Nurdağ i ilçelerinde bulurken, en az ekim-dikim ve gübreleme makineleri \% 1.47 ile Şehitkamil ilçesinde olduğu görülmektedir. Ekim makinesi ile ilçe dağılımları ile üretim şekli arasında tarım alanlarının kullanım amaçlarına göre dağılımına bakıldığında bir paralelliğinin olduğu, kullanılan alanların bir kısmın ekili tarla alanı olduğu, tarla alanından sonra en çok alanın çeşitli nedenlerle nadasa bırakılmış araziler olduğu görülmektedir.

İl genelinde bulunan önemli bazı hasat ve harman makineleri Çizelge 8 'de verilmiştir. Veriler incelendiğinde, en yaygın bulunan hasat ve harman makinesinin traktörle çekilen çayır biçme makinesi olduğu (\% 44.31), bunu sap döver harman makinesi ( $\%$ 36.45) ve orak makinesinin (\% 32.12) takip ettiği görülmektedir. 
Çizelge 8. Hasat ve harman makinelerinin ilçelere göre dă̆ı̆lımı (Anonim, 2011a)

\begin{tabular}{lcccccccc}
\hline İlçeler & $\begin{array}{c}\text { Ot } \\
\text { Tırmı̆ı }\end{array}$ & $\begin{array}{c}\text { Orak } \\
\text { Makinası }\end{array}$ & $\begin{array}{c}\text { Biçer } \\
\text { Bağlar } \\
\text { Makinası }\end{array}$ & $\begin{array}{c}\text { Traktörle } \\
\text { Çekilen } \\
\text { Çayır } \\
\text { Biçme } \\
\text { Makinası }\end{array}$ & $\begin{array}{c}\text { Misır Silaj } \\
\text { Makinası }\end{array}$ & $\begin{array}{c}\text { Sap } \\
\text { Parçalama } \\
\text { Makinası }\end{array}$ & $\begin{array}{c}\text { Sap Döver } \\
\text { Harman } \\
\text { Makinası }\end{array}$ & $\begin{array}{c}\text { Toplam } \\
\text { (adet) }\end{array}$ \\
\hline Sahinbey & 30 & 100 & 5 & 150 & 60 & 8 & 90 & 443 \\
Şehitkamil & 4 & 70 & 0 & 5 & 10 & 0 & 20 & 109 \\
Araban & 0 & 0 & 0 & 72 & 1 & 3 & 0 & 76 \\
İslahiye & 0 & 0 & 2 & 0 & 0 & 7 & 4 & 13 \\
Kargamiş & 0 & 0 & 0 & 0 & 0 & 3 & 35 & 38 \\
Nizip & 10 & 10 & 0 & 20 & 5 & 5 & 70 & 120 \\
Nurdağı & 11 & 25 & 1 & 6 & 17 & 16 & 18 & 94 \\
Oğuzeli & 14 & 71 & 2 & 187 & 35 & 36 & 69 & 414 \\
Yavuzeli & 28 & 6 & 0 & 3 & 2 & 0 & 14 & 53 \\
\hline Gaziantep & 97 & 282 & 10 & $\mathbf{3 8 9}$ & 100 & 78 & 320 & $\mathbf{8 7 8}$ \\
\hline
\end{tabular}

Hasat ve harman makinelerinin ilçeler bazındaki dağılımı incelendiğinde Şahinbey ilçenin \% 50.46 ile birinci sırada yer aldığı, bunu \% 47.15 ile Oğuzeli ve \%12.41 ile Şehitkamil ilçelerinin takip ettiği belirlenmiştir.

Diğer önemli bazı tarım alet ve makinelerinin varlı̆ğ incelendiğinde, Gaziantep ilinde tarım arabasının yoğun bir şekilde kullanıldığı görülmektedir. İl genelinde toplam 8953 adet tarım arabası bulunurken, 1834 adet derin kuyu pompası, 2861 adet de süt sağım tesisinin, 692 adet santrifüj pompa, 335 adet yağmurlama tesisi ve 29 adet de süt sağım tesisi bulunmaktadır (Çizelge 9).

Çizelge 9. Diğer tarım alet ve makinelerinin il genelindeki varlığı (Anonim, 2011a)

\begin{tabular}{lcccccc}
\hline \multicolumn{1}{c}{ İlçeler } & $\begin{array}{c}\text { Santrifüj } \\
\text { Pompa }\end{array}$ & $\begin{array}{c}\text { Derin Kuyu } \\
\text { Pompa }\end{array}$ & $\begin{array}{c}\text { Yağmurlama } \\
\text { Tesisi }\end{array}$ & $\begin{array}{c}\text { Süt Sağım } \\
\text { Tesisi }\end{array}$ & $\begin{array}{c}\text { Römork (Tarım } \\
\text { Arabas1) }\end{array}$ & $\begin{array}{c}\text { Toplam } \\
\text { (adet) }\end{array}$ \\
\hline Şahinbey & 35 & 160 & 15 & 12 & 2100 & 2.322 \\
Şehitkamil & 5 & 500 & 0 & 2 & 1000 & 1.507 \\
Araban & 12 & 460 & 122 & 0 & 857 & 1.451 \\
İslahiye & 50 & 187 & 116 & 5 & 567 & 925 \\
Kargamiş & 75 & 90 & 0 & 0 & 685 & 850 \\
Nizip & 340 & 9 & 18 & 4 & 1400 & 1.771 \\
Nurdağı & 18 & 301 & 45 & 5 & 790 & 1.159 \\
Oğuzeli & 136 & 100 & 17 & 0 & 1224 & 1.477 \\
Yavuzeli & 21 & 27 & 2 & 1 & 330 & 381 \\
\hline Gaziantep & 692 & 1.834 & 335 & 29 & 8.953 & 11.843 \\
\hline
\end{tabular}

Çalışmanın sonunda elde edilen sonuçlar aşağıda verilmiştir.

- Gaziantep ilinin tarımsal mekanizasyon özelliklerinin belirlenmesi amacıyla yapılan bu çalışmada, işlenen tarım alanına düşen traktör gücü ortalama traktör gücü Türkiye ortalamasından $\% 14$, Avrupa Birliği ortalamasından ise $\% 65$ daha düşüktür. Ortalama traktör gücü değeri ilçeler bazında incelendiğinde hem Nurdağı hem de Araban ilçelerinin Türkiye ortalamasının üzerinde veya eş değer olduğu görülmektedir. Oğuzeli, Kargamış, Şehitkamil ve Şahinbey ilçeleri ise ortalama traktör gücü bakımından il ortalamasının altında kalmaktadır. 1000 ha işlenen alana düșen traktör sayısı bakımından Türkiye Avrupa Birliği ülkelerinin \%20 gerisinde yer alırken, Gaziantep ili'de Türkiye ortalamasının $\% 54$ gerisinde yer almaktadır. Traktör başına düşen alet-makine sayısı bakımından Türkiye 6.32 makine traktör ${ }^{-1}$, Avrupa Birliği ise 10 makine traktör ${ }^{-1}$ ortalamalarına sahiptirler.
Türkiye Avrupa Birliği ülkelerinin \% 39 gerisinde yer alırken, Gaziantep ili'de Türkiye ortalamasının \% 37 gerisinde yer almaktadır. Birim alana düşen traktör gücü, Avrupa Birliği ülkeleri için ortalama $6 \mathrm{~kW} \mathrm{ha}^{-1}$ iken bu değerin Türkiye ortalaması $2.91 \mathrm{~kW} \mathrm{ha}{ }^{-1}$, Gaziantep ili ortalaması ise $1.17 \mathrm{~kW} \mathrm{ha}^{-1}$ dır. Türkiye ortalaması Avrupa Birliği ülkelerinin ortalamasına göre \% 52 daha düşük, Gaziantep ile ise Türkiye ortalamasına göre $\% 60$ daha düşük değerdedir. $\mathrm{Bu}$ değer Gaziantep ilindeki mekanizasyon seviyesinin oldukça geride olduğunun açık bir göstergesidir. Tarım arazilerinin parçalı yapıda olması, traktör ve tarım alet makine kullanımını sınırlandırmıștır.

- Gaziantep ili genelinde tarım yapan tarımsal işletmelerin mekanizasyon durumunun belirlenmesi amacıyla yapılan bu araştırmadan elde edilen sonuçlar ve tarımsal etkinliğin artırılabilmesi için yapılacak öneriler aşağıda verilmiştir. 
- Tarımsal mekanizasyon düzeyi değerlerinin düşüklüğü yanında, ülkemizde makine kullanımındaki etkinliğin de az olduğu bir gerçektir. Tarım arazilerinin parçalı ve ortalama işletme arazi değerlerinin düşük olması traktör ve tarım alet ve makineleri kullanımındaki verimliliği de azaltmaktadır. Ayrıca, işletme arazi değerlerinin düşük ve aynı zamanda tarımsal nüfusun da fazla olması, işletme ve fert başına düşen tarımsal gelirin azalmasına neden olan traktör ve ekipman talebini de azaltmaktadır. Türkiye'de nüfusun \% 25'ten fazlasının tarım kesiminde çalışmasına karşılık gelir payının çok düşük olması tarımsal mekanizasyon özelliklerini de etkilemektedir. Tarımsal nüfustaki fazlalığın azaltılması ve işletme arazilerinin birleştirilmesiyle, işletme ve kişi başına düşen gelirin artması tarımsal mekanizasyondaki gelişmeyi de artıracaktır.

- Toprak işleme alet ve makinaları verilerinden yola çıkılarak il genelinde geleneksel toprak işleme yönteminin yaygın olarak uygulandı̆̆ varılmıştır. Toprak işleme alet ve makineleri varlığı en çok Şahinbey ilçede bulunmaktadır. Gaziantep'te bitkisel üretimin temel konularının başında toprak işleme gelmektedir. Bu yüzden toprağın korunmasının temel amaç olduğu ve masraflarının/enerji girdilerinin en az seviyede oldu koruyucu toprak işleme sistemlerinin çiftçilere tanıtılması önem arz etmektedir.

- Gaziantep ili genelinde tarımsal mücadelede çoğunlukla sırt pülverizatöründen yararlanılmaktadır. Sirt pülverizatörlerinin hem bağ ve bahçelerde, hem de küçük ölçekli tarla arazilerinde rahatlıkla kullanılabilmesi, bu makinenin yaygın bir şekilde tercih edilmesine neden olmuştur. Bunun yanı sıra girdi masraflarının azaltılmasına yönelik uygulamaların hayata geçirilmesi de gelir düzeyinin artışına olumlu yönde katkı sağlayacaktır.

- Gaziantep il genelinde önemli bazı ekim-dikim ve gübreleme makineleri içerisinde santrifüjlü gübre dağıtma makinesinin (\% 43.26) ilk sırada yer aldığı dikkat çekmektedir. Bunu sırası ile; kombine ekim makinesi (\% 36.01), traktörle çekilen hububat ekim makinesi (\% 4.65), pnömatik ekim makinesi (\% 2.18) ve çiftlik gübresi dağıtma makinesi ( $\%$ 0.69) takip etmektedir. Gaziantep ilinde; kimyevi gübre dağıtma makinesi toplam 2.325 adet olup, bu makinelerin çoğunluğu Araban ilçede bulunmaktadır. Yöre halkı kimyevi gübre dağıtma makinesini serpme ekim yönteminde kullanabilmektedir. Ekim-dikim ve gübreleme makinelerinin ilçelere göre dağılımı incelendiğinde; ilde bulunan alet ve makinelerinin en fazla \% 22.63 ile Oğuzeli ilçesinde, en az ekim-dikim ve gübreleme makineleri \% 1.47 ile Şehitkamil ilçesinde olduğu görülmektedir. Düşük gelirli ve küçük ölçekli arazilere sahip işletmelerin diğer işletmelerle rekabetinin sağlanabilmesi için, modern üretim teknolojilerini kullanmalarını sağlayacak ortak makine kullanımı gibi organizasyonlara gerek vardır.

\section{KAYNAKLAR}

Altıkat, S., Çelik, A., 2009. Erzurum İlinin Tarımsal Mekanizasyon Özellikleri. Atatürk Üniversitesi Ziraat Fakültesi Dergisi, 40 (2):57-70.

Anonim. 2001. Sekizinci Beş Yıllık Kalkınma Planı Tarım Alet ve Makinaları Sanayii Özel İhtisas Komisyonu Raporu

Anonim, 2011a. Tarımsal Alet ve Makina Sayıları Veri Taban1. http://tuikapp.tuik.gov.tr/bitkiselapp/tarimalet.zul

Anonim, 2011b. Bitkisel Üretim İstatistikleri Veri Taban1. http://tuikapp.tuik.gov.tr/bitkiselapp/bitkisel.zul

Çelik, A., Öztürk, İ., Turgut, N., 2002. Gümüşhane ili tarımsal mekanizasyon özellikleri. Gümüşhane ve Yöresinin Kalkınma Sempozyumu, 23-25 Ekim Gümüşhane.

Dilay, Y., A. Özkan. 2007. Karaman İl'indeki Tarım Makinaları İmalatçılarının Durumu ve Sorunları. Tarımsal Mekanizasyon 24. Ulusal Kongresi, Kahramanmaraş.

Erkmen, Y., Çelik, A., 1992. Ağrı ilinin tarımsal mekanizasyon özellikleri, sorunları ve çözüm olanakları üzerine bir araştırma. Tarımsal Mekanizasyon 14. Ulusal Kongresi, 14-16 Ekim, Samsun.

Sabancı, A., Akıncı, İ., 1994. Dünyada ve Türkiye'de Tarımsal Mekanizasyon Düzeyi ve Son Gelişmeler. Tarımsal Mekanizasyon 15. Ulusal Kongresi Bildiri Kitab1. S: 404-415 (20-22 Eylül, 1994), Antalya.

Sessiz, A., Gürsoy, S., Eliçin, A.K., Akın, S., Esgici, R., 2012. Diyarbakır İli Tarımsal Mekanizasyon Durum Analizi ve Planlaması Projesi. Dicle Üniversitesi Ziraat Fakültesi Tarım Makinaları Bölümü.

Ülger, P., Güzel, E., Kayışoğlu, B. Eker, B., Akdemir, Y., Pınar, Y. Bayhan, Y., 1996. Tarım Makinaları İlkeleri. T.Ü. Tekirdağ Ziraat Fakültesi, Ders Kitabı, No:29, S:435, Fakülteler Matbaası, İstanbul.

Ülger, P., Güzel, E., Kayışoğlu, B., Eker, B., Akdemir, B., Pınar, Y., Bayhan, Y., Aktaş., T., Sağlam, C., Toruk, F., Gönülol, E. Çelen, İ.H., 2011. Tarım Makinaları İlkeleri. Hiperlink Yayınları, İstanbul.

Yalçın, Ö. F., 1990. Ankara İlinde Traktör Mülkiyeti ve Rasyonel Kullanımı Üzerine Bir Araştırma. Ankara Üniversitesi Ziraat Fakültesi Yayınları: 1179, Ankara. 